\title{
A new species of Sigmodontinae (Rodentia) from the late Hemphillian of central Mexico, and comments on the possible radiation of this group
}

\author{
Adolfo Pacheco-Castro ${ }^{1, *}$, Oscar Carranza-Castañeda ${ }^{2}$, and Eduardo Jiménez-Hidalgo ${ }^{3}$ \\ ${ }^{1}$ Posgrado en Ciencias de la Tierra, Centro de Geociencias, Universidad Nacional Autónoma de México, \\ Boulevard Juriquilla 3001, Juriquilla, Querétaro 76230, Mexico. \\ ${ }^{2}$ Centro de Geociencias, Universidad Nacional Autónoma de México, \\ Boulevard Juriquilla 3001, Juriquilla, Querétaro 76230, Mexico. \\ ${ }^{3}$ Laboratorio de Paleobiología, Instituto de Recursos, campus Puerto Escondido, Universidad del Mar, \\ Carretera Puerto Escondido-Oaxaca km 2.5, C.P, 71985, Oaxaca, Mexico. \\ *apacheco@geociencias.unam.mx
}

\begin{abstract}
The Sigmodontinae subfamily represents one of the most diverse groups of mammals in the world; this rodent group evolved in the open and arid ecosystems of the Miocene of North America and was the most successful legion of mammals in the Great American Biotic Interchange. Part of its diversification occurred in the Mexican Pliocene, in the Hemphillian-Blancan boundary, where Prosigmodon and Sigmodon species are very common. Recent molecular phylogenetic systematics research proposes that Sigmodon is related to South American sigmodontines, while studies of classical morphometry in isolated molar teeth consider Prosigmodon as a junior synonymy of Sigmodon, which modifies the biogeographic and chronostratigraphic interpretations of this group in America. In this paper, we describe a new species of Prosigmodon from the late Hemphillian ( 4.89 Ma) of central Mexico based on jaws, maxillary and complete isolated teeth. This is the most complete and austral record of the genus in North America. This species was compared with North American species of the Sigmodontinae and Neotominae subfamilies and we defined it as a new Prosigmodon species characterized by having a consistently present minute mesoloph in M1 and M2, in addition, there is an isolated metaconid from the protoconid in the $\mathrm{m} 1$ of young individuals.

We performed a phylogenetic model using osteodental morphological characters focused on understanding the relationship between Prosigmodon (four species) and Sigmodon (eight species), also we included Baiomys (two species), Neotoma (two species), Peromyscus (two species), and Reithrodontomys (two species). Our results indicate that Prosigmodon is a monophyletic group if Sigmodon minor is included within the genus and $P$. chihuahuensis is excluded. The Mexican Prosigmodon species have more apomorphic characters with respect to $S$. minor and P. holocuspis. The species of Prosigmodon and Sigmodon are not closely related. The Sigmodon species are more closely related to the Neotoma species than to the species of Baiomys, Prosigmodon, Reithrodontomys and Peromyscus. Based on
\end{abstract}

the topology of our cladogram and the stratigraphic ranges of the species of Sigmodontinae and Neotominae, we discuss that Baiomys, Prosigmodon, Reithrodontomys and Peromyscus probably diversified in the early Hemphillian (late Miocene), while Sigmodon and Neotoma did so during the late Pliocene.

Key words: Rodentia; Sigmodontinae; Prosigmodon; Late Hemphillian; Central Mexico; Phylogeny.

\section{RESUMEN}

La subfamilia Sigmodontinae es uno de los grupos de mamíferos más diversos del mundo; este grupo de roedores evolucionó en los ecosistemas abiertos y áridos del Mioceno de Norteamérica y fue la legión de mamíferos más exitosa durante el Gran Intercambio Biótico Americano. Parte de esta diversificación ocurrió en México durante el Plioceno, en el límite Henfiliano-Blancano, siendo los representantes más comunes las especies pertenecientes a Prosigmodon y a Sigmodon. Trabajos recientes de sistemática filogenética molecular proponen que Sigmodon está relacionado con los sigmodontinos sudamericanos, mientras que estudios de morfometría clásica en fósiles de molares aislados consideran a Prosigmodon como una sinonimia de Sigmodon, lo que tiene un impacto importante en las interpretaciones biogeográficas y cronoestratigráficas de este grupo en América. En este manuscrito describimos una nueva especie de Prosigmodon del Henfiliano tardio ( 4.9 Ma) del centro de México con base en mandíbulas, maxilares y dientes aislados completos. Este es el registro más completo del género y también el más austral en Norteamérica. Esta especie se comparó con especies norteamericanas de las subfamilias Sigmodontinae y Neotominae y la erigimos como una nueva especie de Prosigmodon caracterizada por tener un mesolofo pequeño consistentemente presente en el M1 y M2, además de que en el $m 1$ de individuos jóvenes el metacónido está aislado del protocónido. Se realizó un modelo filogenético con base en caracteres morfológicos osteodentales 
para entender la relación entre Prosigmodon (cuatro especies) y Sigmodon (ocho especies) donde fueron incluidos también Baiomys (dos especies), Neotoma (dos especies), Peromyscus (dos especies) y Reithrodontomys (dos especies). Nuestros resultados indican que Prosigmodon es un grupo monofilético si se incluye Sigmodon minor y se excluye a P. chihuahuensis. Las especies de Prosigmodon mexicanas tienen caracteres apomórficos con respecto a $S$. minor y P. holocuspis. Las especies de Prosigmodon y Sigmodon no están cercanamente relacionadas, Sigmodon está más relacionado con las especies de Neotoma que con las especies de Baiomys, Prosigmodon, Reithrodontomys y Peromyscus. Con base en la topología de nuestro cladograma y los rangos estratigráficos de las especies de Sigmodontinae y Neotominae discutimos que Baiomys, Prosigmodon, Reithrodontomys y Peromyscus probablemente se diversificaron en el Henfiliano temprano (Mioceno tardío), mientras que Sigmodon y Neotoma lo hicieron durante el Plioceno tardío.

Palabras clave: Rodentia; Sigmodontinae; Prosigmodon; Henfiliano tardío; centro de México; filogenia.

\section{INTRODUCTION}

The Sigmodontinae (Cricetidae) is one of the most diverse rodent subfamilies in America, with approximately 87 genera and 452 species (Burgin et al., 2018). At present, this diversity is concentrated in South America with 82 genera and 400 species (Parada et al., 2013), but its origin dates from the Miocene of North America where seven genera and 33 fossil species have been reported (Lindsay, 2008).

During the early Pliocene, the basins of central Mexico were sites with a high diversity of rodents, mainly species of the subfamilies Sigmodontinae and Neotominae. At least eight species have been formally described: Baiomys kolbi, Bensonomys elachys, Bensonomys baskini, Bensonomys winklerorum, Neotoma (Paraneotoma) sawrockensis, Prosigmodon chihuahuensis, Prosigmodon oroscoi, Prosigmodon ferrusquiae and Postcopemys chapalensis (Carranza-Castañeda and Walton, 1992; Rincón et al., 2016). Also, the stratigraphic record of Prosigmodon and Neotoma (Paraneotoma) in central Mexico is older than in USA localities (Carranza-Castañeda and Walton, 1992, PeláezCampomanes and Martin, 2005).

In the late Hemphillian faunas of central Mexico, the Prosigmodon species are the most diverse and abundant small mammals. Previous studies have indicated that this genus could be related with Democricetodontini species, and several authors proposed the hypothesis of the lineage Copemys-Calomys (Bensonomys)-ProsigmodonSigmodon. In this idea, Copemys species are related with Asian cricetids, and part of this group evolved into Calomys (Bensonomys) and Prosigmodon during the Miocene in the South of North America. Then, during the Pliocene, descendants of Prosigmodon evolved into Sigmodon species and were adapted to the arid environments in the Great Plains of North America (Baskin, 1978; Jacobs and Lindsay, 1981; Lindsay and Jacobs, 1985).

The chronological and taxonomical range of Sigmodon is a controversial subject, because morphological comparisons of Sigmodon species from the Blancan of Kansas, USA, with Prosigmodon species of the late Hemphillian-early Blancan of Mexico showed that Prosigmodon is a synonym of Sigmodon (Peláez-Campomanes and Martin, 2005). This implies that the stratigraphic record of Sigmodon started in the early Hemphillian (Hh1) from Dove Spring Formation (Whistler et al. 2009) and continues today, and this would mean that this genus is one of the longest known groups of mammals since the Miocene.

Recent systematic models based on isolated teeth of cricetid species proposed that Prosigmodon is a polyphyletic group with Prosigmodon holocuspis in the base of Sigmodon clade, and the Mexican Prosigmodon species P. chihuahuensis, P. ferrusquiae and P. oroscoi in their own clade (Rincón et al., 2016). Also, Rincon et al. (2016) proposed that Sigmodon is more related to Repomys, Nelsonia, Neotoma and Reithrodontomys than to the Mexican Prosigmodon species; this hypothesis contrasts with previous ideas that linked Prosigmodon with Sigmodontinae rather than Neotominae species (Peláez-Campomanes and Martin, 2005; Lindsay, 2008). This re-opens the discussion about the taxonomic limits of these genera and the phylogenetic relationship between Democricetodonini, Sigmodontinae and Neotominae species.

Part of the problem of the Prosigmodon/Sigmodon synonymy is that their anatomical comparisons necessarily have been made only with isolated teeth, even the jaws or maxillary fragments are very rare in the Pliocene fossil record. There is no phylogenetic analysis that considers complete fossil dental material, and precise radiometric ages to understand the evolution of this group in North America.

The purpose of this paper is to describe a new species of Prosigmodon from the late Hemphillian (Hh3) of Tecolotlán basin, Jalisco, in central Mexico. The material was discovered in one of the best-studied late Hemphillian (Hh3) mammal associations of Mexico, with precise ${ }^{40} \mathrm{Ar} /{ }^{39} \mathrm{Ar}$ ages of $4.89 \pm 0.16 \mathrm{Ma}$ (Kowallis et al., 1998). The specimens of Prosigmodon in this locality are abundant, well preserved, with complete jaws in different stages of tooth wear, which helped to clarify its taxonomic status with respect to Sigmodon. Also, we propose a phylogenetic hypothesis for Prosigmodon species and North American Sigmodon species: we included specific species of Sigmodontinae, Neotominae and Democricetodontini which have been related by morphological methods in previous paleontological studies. The purpose of this phylogenetic model is to get a better understanding of the relation between Prosigmodon and Sigmodon, and not to understand the systematics of Neotominae and Sigmodontinae.

\section{METHODS}

\section{Geological setting}

The Tecolotlán basin in Jalisco state is located $110 \mathrm{~km}$ to the southwest of Guadalajara city, in the northeastern part of the Jalisco block, in west-central Mexico (Figure 1). The basin has an extension of $20 \mathrm{~km}$ and is $10 \mathrm{~km}$ in width, and it is part of numerous small basins parallel to the large basin of Tepic-Zacoalco (Kowallis et al., 2010, 2017).

The fossil material reported in this work was collected in the local-

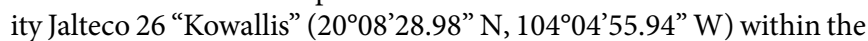
fluvial sedimentary sequence of San Jose formation (informally formation) (Carranza-Castañeda, 2006; Kowallis et al., 2010, 2017) (Figure 1).

The locality was discovered in the 1980s by Mr. Harley J. Garbani and Oscar Carranza-Castañeda during the first stages of research in the Tecolotlán basin. Later we began research to study the small vertebrates of the basin collected since 2005, which contributes to different projects at Laboratorio de Paleontología, Centro de Geociencias, UNAM.

\section{Stratigraphy and depositional environment}

The stratigraphic succession at the locality Jalteco 26 "Kowallis" in the formation of San Jose is composed of an alternation of siltstones and mudstones. The siltstones and mudstones alternate their coloration cyclically from gray-green to reddish. Few sandstone lenses and caliche layers are present. At the base of the succession a sandstone with parallel lamination crops out, and this is interpreted as sedimentation in a high hydrodynamic regime. The middle and the top of the succession are dominated by massive strata of siltstones, mudstones and fine sandstone: these geological structures are interpreted as fluvial and overbank deposits (Figure 2) (Kowallis et al., 2017). 


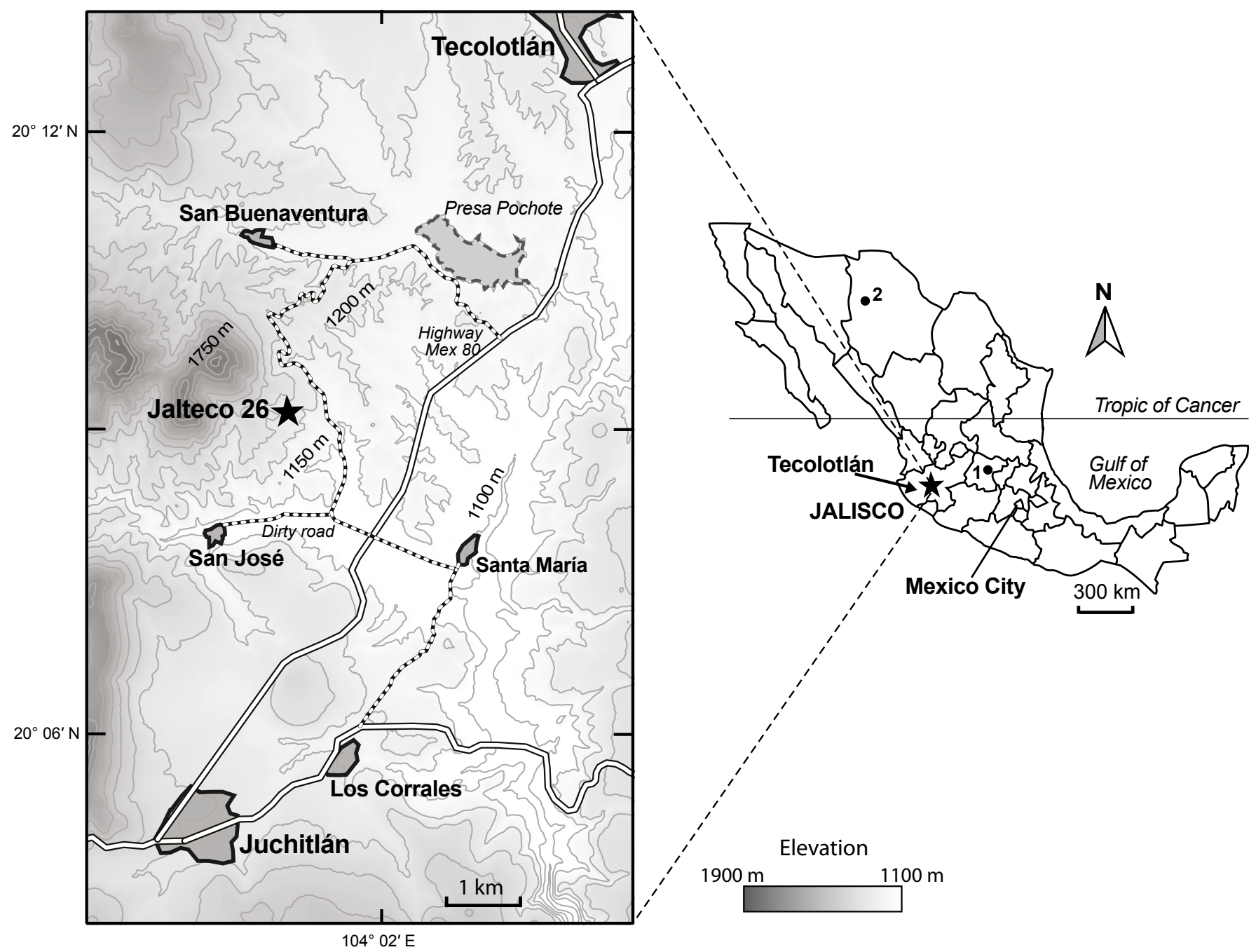

Figure 1. Location map of Tecolotlán basin, Jalisco in central Mexico. Black star indicates the fossil locality Jalteco 26 "Kowallis", black circles are the places where cricetid rodents of the Neogene have been reported: 1) San Miguel de Allende basin, Guanajuato state; 2) Yepomera basin, Chihuahua state.

Age control in the localities comes from volcanic ash at the top of the sequence and late Hemphillian faunas (Hh3). The volcanic ash in Jalteco 26 "Kowallis" has been dated at $4.89 \pm 0.16 \mathrm{Ma} \mathrm{by}{ }^{40} \mathrm{Ar} /{ }^{39} \mathrm{Ar}$ (Kowallis et al., 1998). Just above this volcanic ash, lenses of sandstone rich in small vertebrates crops out, mainly yielding cricetid rodents, lagomorphs, fishes, amphibians, reptiles and birds. The Hemphillian fauna common in the entire the locality are Neohipparion eurystyle, Dinohippus mexicanus, Teleoceras fossiger, Megatylopus cf. matthewi and Agriotherium schneideri (Carranza-Castañeda, 2006; Kowallis et al., 2017).

\section{Fossil specimens collecting}

The fossil material consists of maxillary and jaw fragments, and isolated complete teeth. Prospecting and collection of fossil material in Tecolotlán basin, Jalisco, was carried out by personnel of the Laboratorio de Paleontología, Centro de Geociencias, Universidad Nacional Autónoma de México (UNAM). The most complete specimens were picked up in situ, and most of the material was collected through screen washing.

Fossils were prepared at Laboratorio de Paleontología, UNAM, and Instituto de Geología, UNAM. The material was cataloged at Laboratorio de Paleontología, Centro de Geociencias, UNAM. Pictures were taken using a scanning electron microscope SEM EVO-50 Carl
Zeiss of the Laboratorio Nacional de Identificación y Caracterización Vegetal (LANIVEG), Universidad Autónoma de Querétaro, and a camera Canon A3400 coupled to a stereomicroscope at Laboratorio de Paleontología, Centro de Geociencias, UNAM. Measurements were taken using the software Morpho J 1.45S.

\section{Anatomical nomenclature}

We use the teeth terminology of Peláez-Campomanes and Martin (2005) that precisely includes the morphology of M2/m2 and M3/m3 (Figure 3), their terminology followed Tomida (1987) and Reig (1977). Also, we use the term "median mure" of Reig (1977) that he used following Wood and Wilson (1936).

Anatomical comparisons included all Prosigmodon species, eight modern and fossil Sigmodon species, two modern Neotoma species, two Reithrodontomys species and Copemys dentalis (Supplementary Table A1). The compared specimens are housed in the following collections: Colección Paleontológica, Centro de Geociencias (MPGJ), Universidad Nacional Autónoma de México (UNAM); Colección Nacional de Paleontología, Instituto de Geología (IGM) UNAM; Colección Nacional de Mamíferos de México (CNMA), UNAM; Vertebrate Paleontology Department and Mammalogy Department of Natural History Museum of Los Angeles County, California, USA (LACM). 


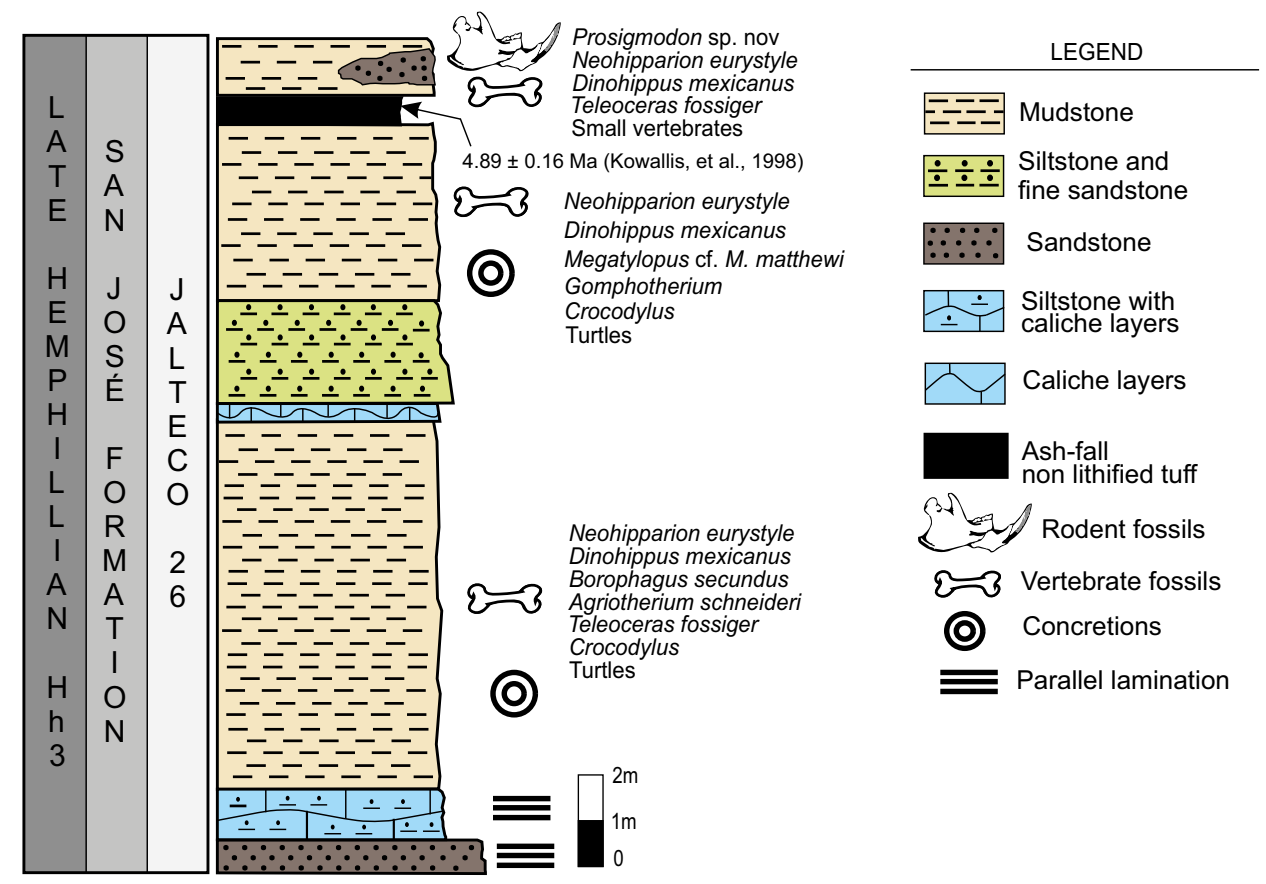

Figure 2. Stratigraphic column of the locality Jalteco 26 "Kowallis", formation of San Jose, late Hemphillian (Hh3), central Mexico.

In the description of the teeth we considered the occlusal wear, with the aim of establishing whether the used taxonomical characters are independent of the ontogeny or the wear stage, and to check whether they are useful in a taxonomic comparison between the Cricetidae species. For this reason, all teeth diagnostic characters were taken from young-adult individuals with little occlusal wear, and we describe the possible character change in the population sample. Only complete teeth were included in this work.

\section{Phylogenetic analysis}

We considered 18 Sigmodontinae and Neotominae taxa and 38 osteodental characters: 33 are discrete characters, following, in part, Steppan (1995), Weksler (2006), and Rincón et al. (2016); five are biometric indexes (Supplementary Tables A1, A2 and A3). The species included in the analysis are: Prosigmodon sp. nov., P. oroscoi, $P$. chihuahuensis and P. ferrusquiae (from late Hemphillian-early Blancan of Mexico); P. holocuspis, Sigmodon curtisi, S. minor/medius (Blancan of USA); S. hispidus (from Rancholabrean, California, USA); Baiomys musculus, B. taylori, Peromyscus mexicanus, P. maniculatus, S. alleni, $S$. arizonae, S. leucotis, S. fulviventer, S. mascotensis, Neotoma albigula, $N$. cinerea, Reithrodontomys chrysopsis and R. megalotis (recent material from Mexico and USA). The outgroup was Copemys dentalis (from Clarendonian of California, USA) because Lindsay (2008) described it as the species with the most plesiomorphic characters of Cricetinae (subfamily that includes Democricetodontini, Megacricetodontini, Sigmodontini and Neotomini tribes), and this relates it to the origin of Sigmodontinae and Neotomini in the North America lineages; also C. dentalis has the most complete osteodental record known for any species of the genus and with precise radiometric and relative ages controls (Whistler et al., 2009).

The phylogenetic analysis was performed with TNT v 1.5, under maximum parsimony using the algorithm of implicit enumeration (Goloboff et al., 2008). Consistency Index (CI) and Retention Index (RI) were also calculated following Farris (1989). The data matrix in TNT format is in Supplementary Material 2.

\section{Abbreviations}

AP, Anteroposterior length; GABI, Great American Biotic Interchange; GTO, Localities in Guanajuato state; GPs, Great Plains of North America; Hh3, Late Hemphillian; Hh4, Latest Hemphillian; Jalteco, Localities in Jalisco state, Tecolotlán municipality; Ma, Millions of years; $\mathrm{M} / \mathrm{m}$, Upper molar and lower molar; NA, North America, NALMA, North American Land Mammal Age; SMA, San Miguel Allende Basin; TMVB, Trans-Mexican Volcanic Belt; USA, United States of America; W, Maximum width.

\section{Institutional abbreviations}

CNMA, Colección Nacional de Mamíferos de México, UNAM; IGM, Colección Nacional de Paleontología, Instituto de Geología, UNAM; LACM, Vertebrate Paleontology Department and Mammalogy Department of Natural History Museum of Los Angeles County, California, USA; MPGJ: Colección Paleontológica of Centro de Geociencias, Universidad Nacional Autónoma de México, UNAM; UNAM, Universidad Nacional Autónoma de México.

\section{SYSTEMATIC PALEONTOLOGY}

Order Rodentia Bowdich, 1821

Family Cricetidae Rochebrune, 1883

Tribe Sigmodontini Wagner, 1843

Genus Prosigmodon Jacobs and Lindsay, 1981

Prosigmodon tecolotum sp. nov.

(Figures 3-5, and Table 1)

Holotype. MPGJ 3638, partial right jaw with i1, m1-m3 of a youngadult specimen (Figure 3a, 3c).

Paratypes. MPGJ-3342, right maxillary fragment with M1-M2 (Figures $3 \mathrm{~b}$ and $4 \mathrm{a}-4 \mathrm{~b}$ ); MPGJ 3336, left maxillary fragment with M2-M3 (Figure 4c-4d); MPGJ 3615, right maxillary fragment with M1; MPGJ 3626 right maxillary fragment with M1-M2; MPGJ 3340, left jaw with m1- 
m3 (Figure 4i-4j); MPGJ 3341, left jaw with m1-m3 (Figure 4k-4l). Diagnosis. Species of Prosigmodon with the following autapomorphies: 1) minute mesoloph consistently present in M1 and M2;2) metaconid isolated from protoconid in $\mathrm{m} 1$ of young individuals and weakly connected metaconid in adult specimens, the metalophid is incipient; 3) the ratio of the anteroposterior length of M1 to the width of the M1 anterocone is near to 2.351 while the same proportion in all other Prosigmodon species is 2.157-2.186 (see result of systematic phylogeny). Also, the new species has an unique combination of characters: the posterior mure is smaller than anterior mure because the enamel connection is weak between the protocone and paracone in the M1, M2 (mainly observed in young specimens); bilobed anterocone in M1 (mainly observed in young individuals), that becomes simple in adult specimens; the mesoflexus of M3 is developed towards the middle region of the protocone; the enamel connection between the protoconid and entoconid of $\mathrm{m} 3$ is thin, mainly in young specimens; the posteroflexid of $\mathrm{m} 3$ is absent in most of the young and adult specimens.
Locality and geological age. Jalteco 26 "Kowallis", formation of San José from Tecolotlán Basin in Jalisco state, central Mexico. The NALMA is late Hemphillian (Hh3), early Pliocene, around 4.89-4.95 $\mathrm{Ma}$ (Kowallis et al., 1998, 2010, 2017).

Etymology. The species name refers to the Prosigmodon rodent of the "tecolote", a word that derives from the Nahuatl "tecolotl" which means "owl". Also, in reference to the municipality Tecolotlán that means owls' place.

\section{Referred material}

Fragments of maxillaries and jaws. Eight maxillary fragments: MPGJ 3334, left maxillary with M1-M2 (Figure 3b); MPGJ 3335, left maxillary with M1; MPGJ 3342, right maxillary with M1-M2 (Figure 4a-4b); MPGJ 3336 (Figure 4c-4d), left maxillary with M2-M3; MPGJ 3344, left maxillary with M1; MPGJ 3345, left maxillary with M2; MPGJ 3615, right maxillary with M1; MPGJ 3626, right maxillary with M1-M2. Seven jaws: MPGJ 3340, left jaw with m1-m3 (Figure

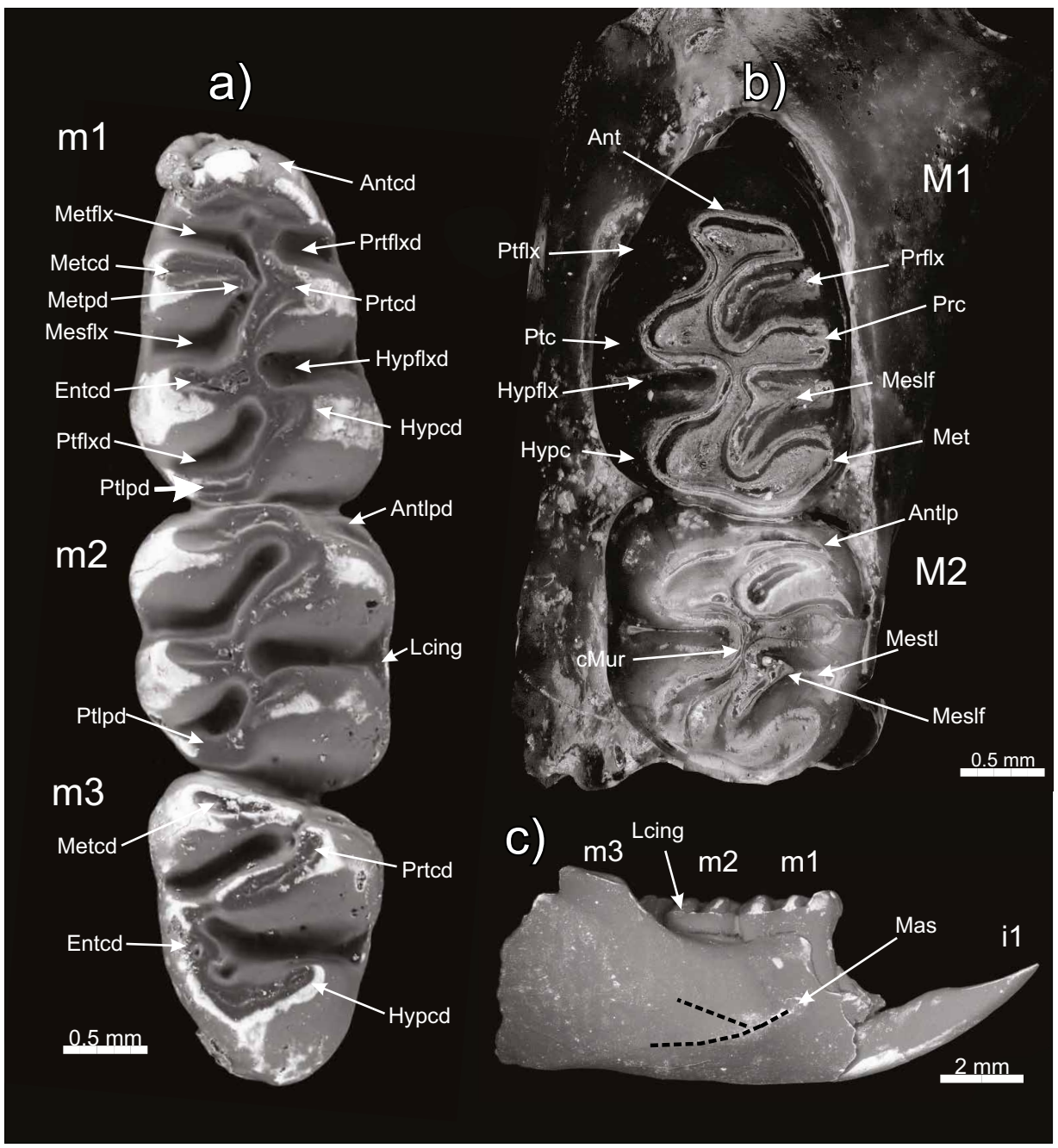

Figure 3. Mandible, lower and upper teeth of Prosigmodon tecolotum. a) occlusal view of holotype MPGJ 3638, right jaw with i1-m3. b) paratype MPGJ 3334, left maxillary with M1-M2; c) labial view of holotype MPGJ 3638, right jaw with i1-m3. Abbreviations of lower elements (m1, $\mathrm{m} 2$ and $\mathrm{m} 3$ ): Antcd, anteroconid; Antlpd, anterolophid; Entcd, entoconid; Hypflxd, hypoflexid; Hypcd, hypoconid; Lcing, labial cingulum; Mas, masseteric ridge (dotted line superior and inferior masseteric ridges); Mesflx, mesoflexid; Metcd, metaconid; Metpd, metalophid; Metflx, metaflexid; Prtcd, protoconid; Ptflxd, posteroflexid; Ptlpd, posterolophid; Prtflxd, protoflexid. Abbreviations of upper teeth (M1, M2 and M3): Ant, anterocone; Prflx, paraflexus; Prc, paracone; Mesflx, mesoflexus; Met, metacone; Ptflx, protoflexus; Ptc, protocone; Hypflx, hypoflexus; Hypc, hypocone; Antlp, anteroloph; Meslf, mesoloph; Mestl, mesostyle; cMur, central mure. Mandible, lower and upper teeth of Prosigmodon tecolotum. 
4i-4j); MPGJ 3341, left jaw with m1-m3 (Figure 4k-4l); MPGJ 3343, right jaw with m2-m3; MPGJ 3638, right jaw with i1-m3 (Figure 3a, 3c); MPGJ 3640, left jaw with m3; MPGJ 3641, left jaw with m1-m3 and MPGJ 3642, right jaw without teeth.

Isolated upper teeth. Eight right M1: MPGJ 1851 (Figure 4e), MPGJ 1852, MPGJ 1855 (Figure 4f), MPGJ 1857, MPGJ 1859 (Figure 4g-4h), MPGJ 3346, MPGJ 3624, and MPGJ 3639. Ten left M1: MPGJ 1835, MPGJ 3347, MPGJ 3618, MPGJ 3619, MPGJ 3620, MPGJ 3621, MPGJ 3622, MPGJ 3627, MPGJ 3628, and MPGJ 3674. Nine right M2: MPGJ 1830, MPGJ 1833, MPGJ 1864, MPGJ 3358, MPGJ 3631, MPGJ 3632, MPGJ 3633, MPGJ 3634 and MPGJ 3637. Thirteen left M2: MPGJ 1829, MPGJ 1831, MPGJ 1834, MPGJ 1862, MPGJ 1868, MPGJ 1870, MPGJ 3337, MPGJ 3338, MPGJ 3356, MPGJ 3357, MPGJ 3635, MPGJ 3636, and MPGJ 3671. Six right M3: MPGJ 1878, MPGJ 3629, MPGJ 3630, MPGJ 3661, MPGJ 3662, and MPGJ 3673. Two leftM3: MPGJ 3354 and MPGJ 3660.

Isolated lower teeth. Eight right m1: MPGJ 1847, MPGJ 3348, MPGJ 3349 (Figure 4o), MPGJ 3350, MPGJ 3647, MPGJ 3648, MPGJ 3650, and MPGJ 3652. Eight left m1: MPGJ 1832, MPGJ 1836, MPGJ 1843, MPGJ 3352, MPGJ 3643 (Figure 4m), MPGJ 3644, MPGJ 3646 (Figure 4n), and MPGJ 3667. Twelve right m2: MPGJ 1839, MPGJ 1863, MPGJ 1874, MPGJ 1875, MPGJ 1887, MPGJ 3669, MPGJ 3670, and MPGJ 3672. Seven left m2: MPGJ 1860, MPGJ 1861, MPGJ 3654, MPGJ 3655, MPGJ 3656, MPGJ 3666, and MPGJ 3668. Two right m3: MPGJ 3664 and MPGJ 3665. Two left m3: MPGJ 3355 and MPGJ 3663.

\section{Description}

Fragment of the right maxillary. Paratype MPGJ 3334 (Figure 3b). The element is composed of an anterior maxillary fragment and the M1-M2. The posterior margin of the zygomatic plate is situated at the margin of the alveolus of M1.

M1. Paratype MPGJ 3334 (Figure 3b). Mesodont tooth with an intermediate size among Prosigmodon species (Table 1). The tooth has five cusps: anterocone, protocone, hypocone, paracone and metacone. The labial and lingual cusps are not aligned, like in most Sigmodontinae species. All the cusps are connected by enamel, but in the center of the

Table 1. Mandibular and teeth measurements of Prosigmodon tecolotum from late Hemphillian, Tecolotlán, Jalisco. Diastema L: diastema length; IW: incisor width; M1 L: M1 length; M2 L: M2 length; M3 L: M3 length; M1 W: M1 width; M2 W: M2 width; M3 W: M3 width; $\mathrm{m} 1 \mathrm{~L}: \mathrm{m} 1$ length; $\mathrm{m} 2 \mathrm{~L}: \mathrm{m} 2$ length; $\mathrm{m} 3 \mathrm{~L}$ : $\mathrm{m} 3$ length; $\mathrm{m} 1 \mathrm{~W}: \mathrm{m} 1$ width; $\mathrm{m} 2 \mathrm{~W}: \mathrm{m} 2$ width; $\mathrm{m} 3 \mathrm{~W}: \mathrm{m} 3$ width; $\mathrm{n}$ : number of samples; s.d.: standard deviation.

\begin{tabular}{lrccc}
\hline & n & $\begin{array}{c}\text { Range } \\
(\mathrm{mm})\end{array}$ & $\begin{array}{c}\text { Mean } \\
(\mathrm{mm})\end{array}$ & s.d. \\
\hline Diastema L & 4 & $2.89-3.4$ & 3.13 & 0.26 \\
I W & 2 & $0.72-0.75$ & 0.74 & 0.02 \\
M1 L & 24 & $2.17-2.87$ & 2.35 & 0.21 \\
M2 L & 27 & $1.58-1.76$ & 1.64 & 0.09 \\
M3 L & 8 & $1.22-1.64$ & 1.45 & 0.15 \\
M1 W & 24 & $1.54-1.88$ & 1.69 & 0.14 \\
M2 W & 27 & $1.54-1.79$ & 1.65 & 0.13 \\
M3 W & 8 & $1.26-1.69$ & 1.41 & 0.17 \\
m1 L & 20 & $2.05-2.41$ & 2.23 & 0.13 \\
m2 L & 23 & $1.56-1.69$ & 1.64 & 0.05 \\
m3 L & 9 & $1.73-2.06$ & 1.88 & 0.14 \\
m1 W & 20 & $1.37-1.69$ & 1.50 & 0.12 \\
m2 W & 23 & $1.41-1.59$ & 1.48 & 0.10 \\
m3 W & 9 & $1.36-1.65$ & 1.51 & 0.11 \\
\hline
\end{tabular}

molar where the mure is formed, the anterior mure is thicker than the posterior mure. The minute mesoloph is consistently present, even in old (worn) specimens like MPGJ 1855 (Figure 4f).

The anterocone is elliptical, with an anteromedial groove slightly developed; this structure is bilobed in young specimens (Figure $4 \mathrm{~g}-4 \mathrm{~h}$ ) and it is simple in adult to old (worn) individuals (Figure 4f). The anterocone medially connects with the protocone and it is situated asymmetrically, more labially with respect to the anteroposterior axis.

The protocone and hypocone are semicircular on the occlusal surface and opened towards the anteroposterior axis. The hypocone is bigger than the protocone. The cusps are connected in the central mure to the paracone, but the connection is incipient in young specimens. The protoflexus and hypoflexus that limit these lingual cusps are deeper and directed at the labial side.

The paracone and metacone are oval on the occlusal surface and they are closed towards the center of the molar. The metacone is bigger than the paracone. The posterior margin of the metacone is irregular because of the development of a small posteroloph.

The hypoflexus is slightly oblique and goes towards the anterior portion of the molar; this character is similar in all Prosigmodon species. The paraflexus and mesoflexus are deeper, and the enamel of each form a "L" on the occlusal surface because these flexi are directed to the posterior molar region. The shape of these flexi are similar in Democricetodontini and in basal Sigmodontini taxa, like Antecalomys, Calomys, Baiomys, Symmetrodontomys and Jacobsomys, and they are very different in the modern Sigmodon, Neotoma and Phyllotini taxa (Harris, 1984; Steppan, 1995; Weksler, 2006; Lindsay, 2008).

The M1 has three roots, one root is under the anterocone, another one is below the metacone, and last one is bigger than the others and is below the protocone and hypocone (Figure $4 \mathrm{~g}-4 \mathrm{~h}$ ). Most specimens have an accessory root (Figure $4 \mathrm{~h}$ ).

M2. Paratype MPGJ 3334 (Figure 3b). Mesodont tooth with an intermediate size among Prosigmodon species (Table 1). The tooth has four cusps: protocone, hypocone, paracone and metacone. These cusps have the same proportions and disposition as seen in the M1 (Figure 3). The main difference is that the anterocone is not developed, instead an anteroloph is present as an extension of the protocone (Figure $3 b$ ).

The molar has three roots, one root is behind the anteroloph and other two are similar to those of M1. Only few specimens have a small accessory root.

M3. Paratype MPGJ 3336 (Figure 4c-4d). Mesodont toot that is similar in size to Prosigmodon holocuspis teeth (Table 1). The molar has four partially fused cusps: protocone, hypocone, paracone and metacone. The hypocone, metacone and posteroloph are fused in the anterior region, and they are separated from the posterior cusps (posteroloph and hypocone) by a deep mesoflexus; this flexus is near to the protoflexus ending. The hypoflexus is smaller in relation to the paraflexus and mesoflexus. The molar has three roots similar to M2.

Fragment of left jaw. Holotype MPGJ 3638 (3a-3c). Jaw with i1, $\mathrm{m} 1-\mathrm{m} 3$, without the angular process and the ascending mandibular branch. In the labial region, the masseteric crest is composed of two ridges that are conjoined under the $\mathrm{m} 2$ as a single crest. The mental foramen opens dorsally in the posterior diastema surface. It is higher than the masseteric ridge. The ascending mandibular branch starts at the posterior edge of the $\mathrm{m} 2$ and it covers the most surface of $\mathrm{m} 3$ from a labial viewpoint (Figure $3 \mathrm{c}$ ). The ratio of the $\mathrm{m} 1-\mathrm{m} 3$ length to the diastema length is less than in Sigmodon species and it is similar to that Prosigmodon chihuahuensis (Table 1).

m1. Holotype MPGJ 3638 (Figure 3a). Mesodont tooth similar in size and ratio to $P$. chihuahuensis (Table 1), with five cuspids: anteroconid, hypoconid, protoconid, metaconid and entoconid. The labial and lingual cuspids are not aligned. The anteroconid is bilobed and 
connected with the protoconid in the middle of the tooth (Figure 3a$3 c$ ). In some adult specimens the anteroconid is single (Figure $4 \mathrm{k}$ ).

The hypoconid and protoconid are elliptical with enamel in occlusal view forming a " $U$ " shape, closed near the anteroposterior axis. The hypoconid is bigger than the protoconid. These cuspids are well connected with the entoconid. The connection between the protoconid and metaconid is minuscule, and in young specimens this connection is not present because the metalophid is not formed (Figures $3 \mathrm{a}$ and $4 \mathrm{~m}$ ). The labial cuspids have a thick cingulum, and this is more developed between the protoconid and the hypoconid.

The paraconid and metaconid are columnar with an elliptical enamel shape, closed near the anteroposterior axis. The entoconid is bigger than the metaconid. The posterolophid is fused with the hypoconid.
The cuspids are separated by flexids. The labial cuspids are deeper and wider than the lingual flexids. The lingual flexids are " $\mathrm{L}$ " shaped similar to those observed in the upper molars but are more oblique. The molar has two roots, one anterior and one posterior, with a very small accessory root (Figure 4o).

m2. Holotype MPGJ-3340 (Figure 4i-4j). The molar has four principal cuspids: protoconid, hypoconid, metaconid and entoconid, and two accessory cuspids: a well-developed posterolophid and a weak anterolophid. These cuspids have the same disposition and proportions as those of $\mathrm{ml}$ (Figure 3a-3c), but the anteroconid is not present, only a small anterolophid; also, the mesoflexid is more oblique and deeper than in $\mathrm{m} 1$. The labial cingulum is more developed in this molar than in $\mathrm{m} 1$. The molar has two roots similar to those on $\mathrm{m} 1$.

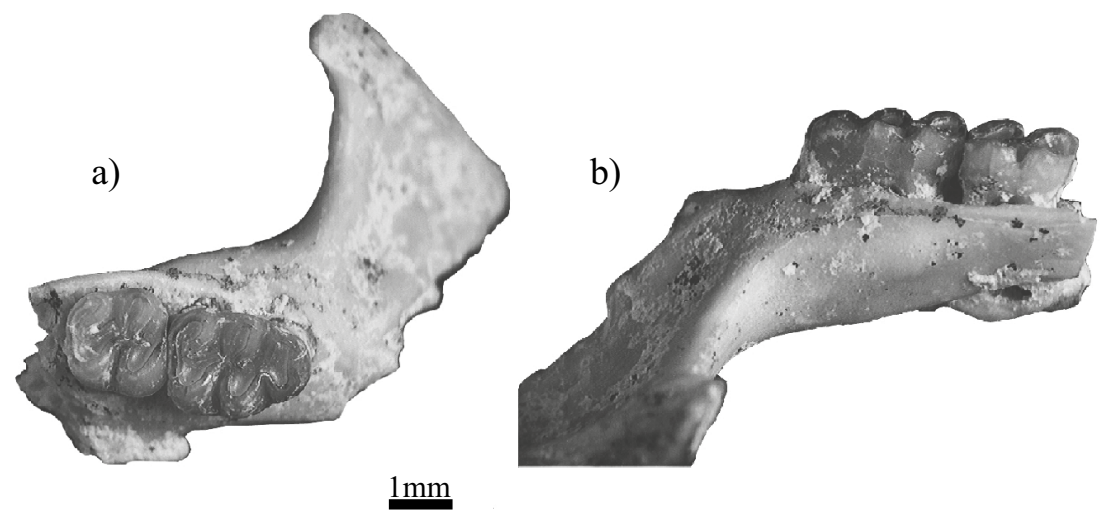

e)

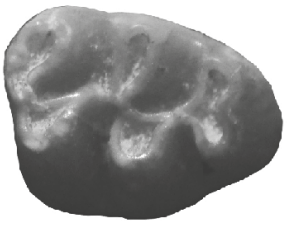

f)
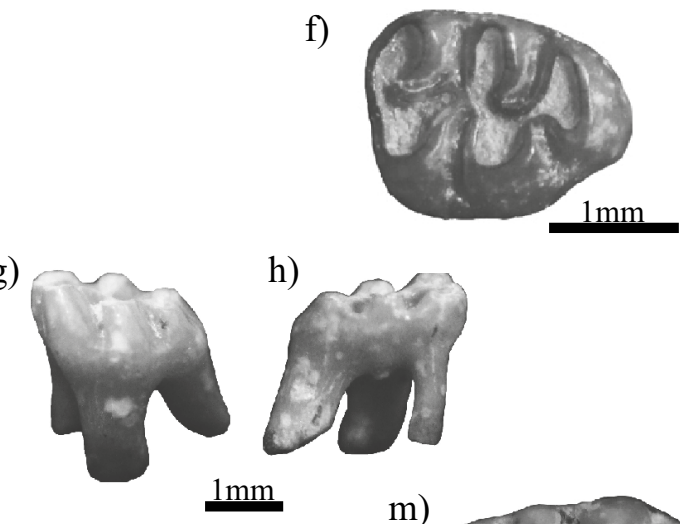

m) i)

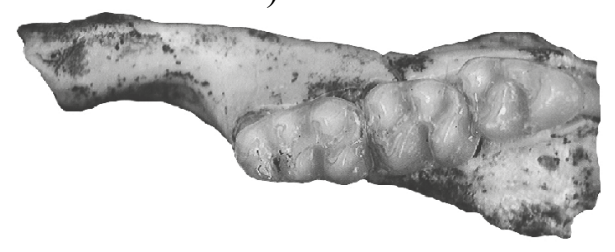

$\mathrm{k})$

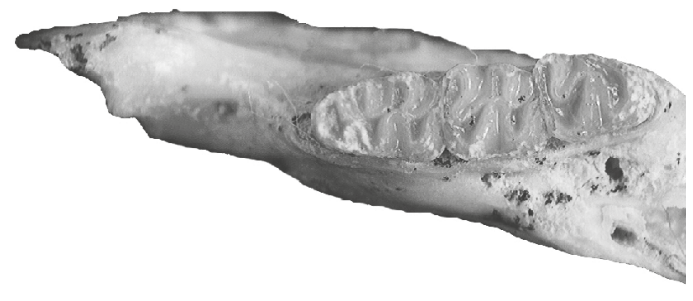

d)

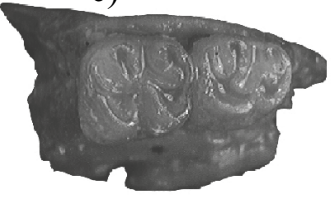

$1 \mathrm{~mm}$

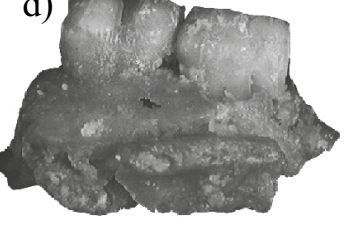

h)

g)

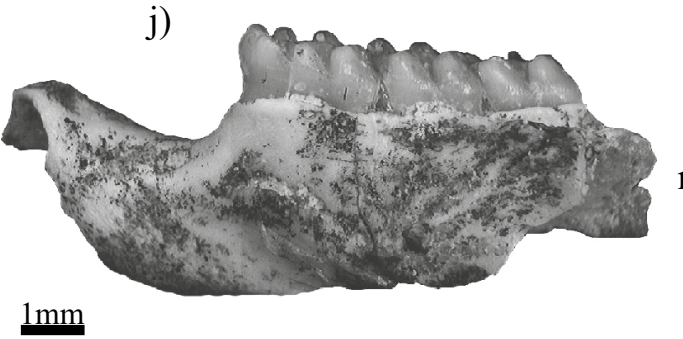

$1 \mathrm{~mm}$
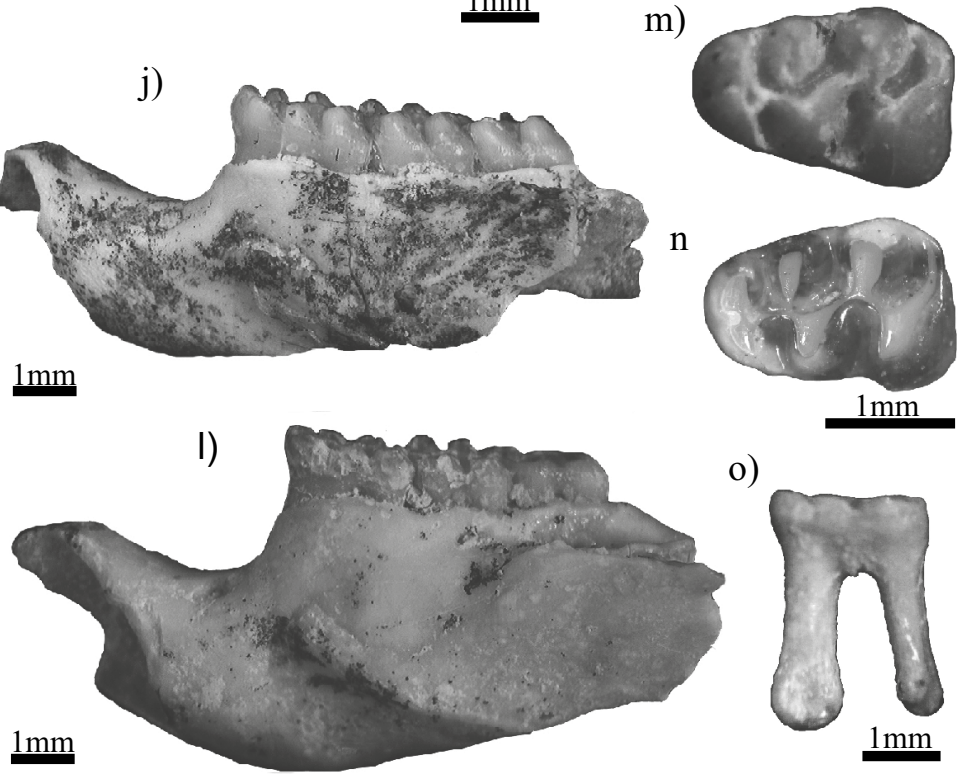

o)

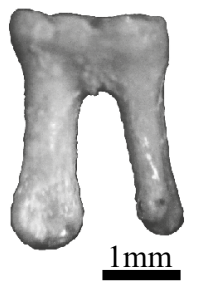

Figure 4. Maxillary, mandibles, upper and lower teeth of Prosigmodon tecolotum; a-b) paratype MPGJ 3342, right maxillary with M1-M2; c-d) paratype MPGJ 3336, left maxillary with M2-M3; e) MPGJ 1851, right M1 of a young specimen; f) MPGJ 1855, right M1 of an adult specimen; g-h) MPGJ 1859, labial and lingual view of right M1; i-j) paratype 3340, left jaw with m1-m3; k-1) paratype 3341, left jaw with m1-m3; m) MPGJ 3643, left m1 of a young specimen; n) MPGJ 3646, left $\mathrm{m} 1$ of an adult specimen; o) MPGJ, 3349, lingual and labial view of right $\mathrm{m} 1$. 
m3. Holotype MPGJ-3340 (Figure 4i-4j). The protoconid and metaconid are well developed, and the hypoconid, entoconid and posterolophid are fused in their posterior margin. The connection between the cuspids is " $\mathrm{S}$ " shaped.

In the anterior region, the metaconid is elliptical and this is connected to the triangular protoconid. The protoconid is connected to the entoconid on the lingual side. The distinction between the entoconid, protoconid and posterolophid is possible only in very young individuals like the paratype MPGJ 3340 (Figure 4i), because in adult specimens all these cuspids are fused and the exposed dentine is continuous. The hypoflexid is deeper than the mesoflexid. The molar has two roots like in $\mathrm{m} 2$.

\section{Comparison of Prosigmodon species}

The teeth of Prosigmodon tecolotum are like all the Prosigmodon species in form and shape but have a special combination of characters and autapomorphies. The most important character in P. tecolotum is the presence of a minute but well developed mesoloph in M1 and M2, this character is not observable in any of the previously described Prosigmodon species.

The M1 of P. tecolotum is very similar to P. chihuahuensis, P. ferrusquiae, P. holocuspis and P. oroscoi, especially in adult specimens where the anterocone and the accessory cusp have wear. In young specimens the anterocone in M1 of P. tecolotum is bifurcated as in the other species of Prosigmodon, but its anteromedial flexus is shallow and not deep a difference with $P$. ferrusquiae and $P$. chihuahuenis, this is more similar to $P$. oroscoi and $P$. holocuspis. The specimens of $P$. tecolotum can be distinguished from $P$. oroscoi because they do not have a paraloph and mesostyle in M1 and M2.

The mesoloph in P. tecolotum is similar to that other Democricetodontini and Megacricetodontini species, its size is that in specimens of Copemys sp. (Fig 5b) and Megacricetodon cf. sinensis (Figure 5c) reported by Jacobs and Lindsay (1984). Our comparative work with Copemys dentalis from Dove Spring Formation shows that not all the specimens have the same development of this structure; in some cases, this structure is almost absent. The development of this structure in P. tecolotum is consistent in almost all specimens (80\%), including M1 and M2, a condition that is not observable in recent Sigmodontinae species like Calassomys apicalis from Brazil, which has a minuscule mesoloph only in M1 and was described by Pardiñas et al. (2014) as a vestigial structure in Phyllotine species (Fig 5a).

The lower $\mathrm{m} 1$ of $P$. tecolotum has an isolated metaconid, chiefly in very young specimens; all Prosigmodon species have this character. In $P$. tecolotum the anteroconid is bifurcated as in P. chihuahuensis and $P$. ferrusquiae, it is different from $P$. holocuspis and $S$. minor that have a single anteroconid. In P. tecolotum and $P$. chihuahuensis an internal fold is present, contrary to what is observed in $P$. ferrusquiae, but $P$. chihuahuensis has a deep anteromedial flexid; also, the conules of $P$. chihuahuensis (Paratype IGM 5817) are more asymmetrical than $P$. tecolotum. Another difference is that in P. tecolotum the anteroconid and the protoconid are connected, and in P. chihuahuenis the connection is between the anteroconid and the metaconid.

\section{A morphological comparison between Prosigmodon and Sigmodon}

The fossil material of Prosigmodon tecolotum from Jalteco 26 is the most complete for Prosigmodon species in North America, with numerous teeth and complete jaw specimens in different wear stages (Figure 3 and Figure 4). This allows a more detailed comparison between the diagnostic structures of Prosigmodon and Sigmodon.

The most important structures in the proposed synonymy between Prosigmodon and Sigmodon, according to Peláez-Campomanes and

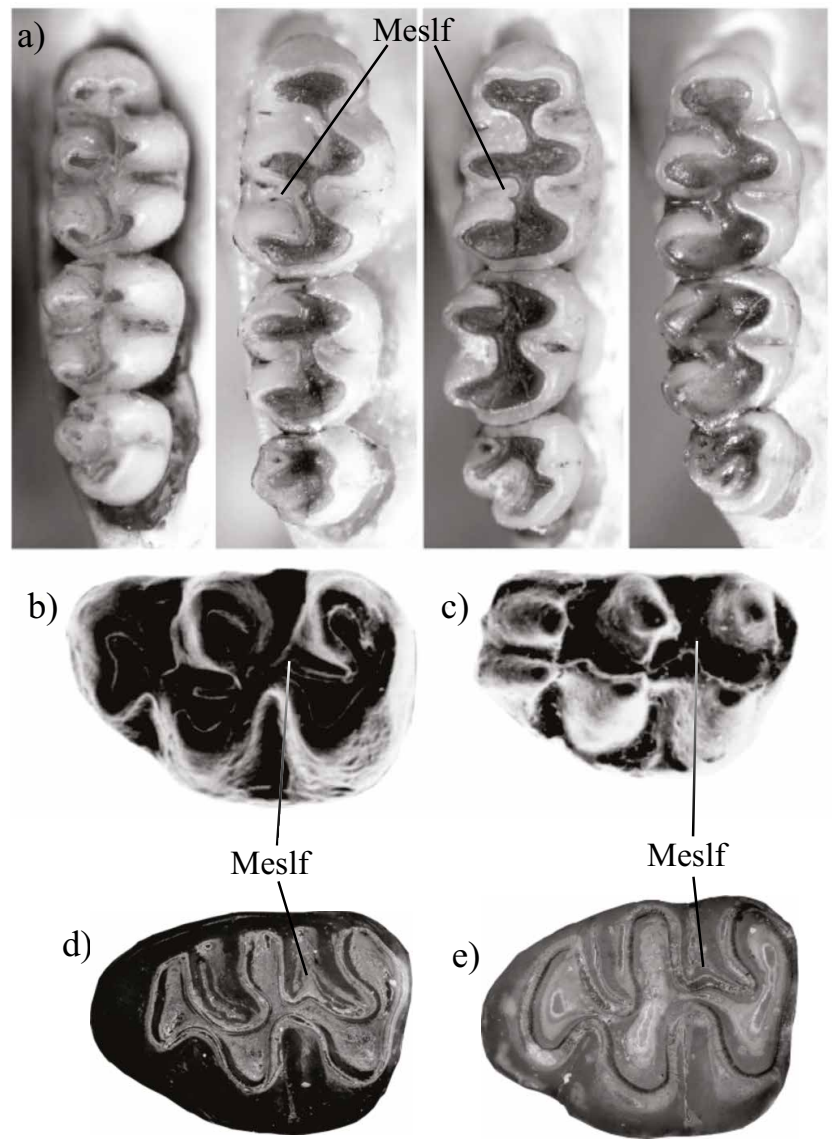

Figure 5. Comparison of mesoloph development in M1 of different Cricetidae species. a) Calassomys apicalis (Sigmodontinae) from Brazil (fig. 4 of Pardiñas et al., 2014), b) Copemys sp. (Democricetodontini) (fig. 1A of Jacobs and Lindsay, 1984), c) Megacricetodon cf. sinensis (Megacricetodontini) (fig. 1B of Jacobs and Lindsay, 1984), d-e) Prosigmodon tecolotum (MPGJ 3344, MPGJ 3334 respectively). Meslf=Mesoloph.

Martin (2005) are the anterocone (id) shape, the enamel connection of the anterocone (id)-protocone (id), and the primitive M3 shape. Here we describe the shape variation of these structures and others that are important to distinguish Prosigmodon from Sigmodon, specifically the mure enamel, the flexus (ids) and the enamel connection of M3 (Figure 3 and Figure 4).

The shape of the anterocone in M1 and the anteroconid in $\mathrm{m} 1$ are important to distinguish the Sigmodon species from the Prosigmodon species. Most authors consider that Sigmodon always has a simple anterocone (id) and Prosigmodon has a bilobed anterocone (id), with Prosigmodon holocuspis as an exception (Jacobs and Lindsay, 1981; Lindsay and Jacobs, 1985; Czaplewski 1987; Carranza-Castañeda and Walton, 1992; Lindsay, 2008). In this study, we observed that the anterocone (id) shape varies in some species of Prosigmodon, especially in those with a large sample, as in Prosigmodon ferrusquiae (Carranza-Castañeda and Walton, 1992) and Prosigmodon tecolotum (Figure 4e-4f). In young individuals of both species the anterocone (id) is bilobed, and in adult specimens with greater tooth wear the anterocone (id) appear simple because the anteromedial groove is not deep; it becomes shallower with wear (Figure 4e-4f, and Figure 4k-4n). If we follow the diagnosis of Lindsay and Jacobs (1985) to identify the material of Tecolotlán, the young specimens would correspond to Prosigmodon and the older specimens would be identified as Sigmodon. 
The lingual connection between the anterocone in M1 and the anteroconid in $\mathrm{ml}$ was important to establish Prosigmodon (Lindsay and Jacobs, 1985) but in a more detailed review of S. minor, S. holocuspis and other Sigmodon species from Blancan faunas it was established that this structure is indistinguishable between the two genera (PeláezCampomanes and Martin, 2005), and it turned out that this structure is described as being more lingually positioned in Prosigmodon than in Sigmodon. In the revision of Prosigmodon species we observed that this character is not easy to evaluate; it can be observed clearly only in the holotype of Prosigmodon oroscoi (IGM 5708 in fig. 1b of Jacobs and Lindsay, 1981) because the molar has a tiny posteroflexus, but in other specimens of the same species and locality the posteroflexus is well developed (e.g., paratype from Yepomera IGM 5807, specimens from SMA IGM 8228 and IGM 8241) and the connection is more medial, similar to all Prosigmodon and Sigmodon species.

Finding a single useful dental character to distinguish both genera is a complicated task, since there is a marked morphological convergence between more recent Democricetodontini and more ancient Sigmodontini species, especially if we only use a single tooth, like M1. A morphological variation on M1 of Copemys, Reithrodontomys Prosigmodon and extinct Sigmodon species is tenuous and difficult to be described. It is more useful to use as many additional teeth loci and characters as possible.

Jacobs and Lindsay (1981) noted the importance of M3 to distinguish Prosigmodon and Sigmodon, but this idea has not been used in the most recent taxonomic studies of the group (Peláez-Campomanes and Martin, 2005; Lindsay, 2008). We think that the M3 is useful to distinguish Prosigmodon from Sigmodon, because it is partially divided into two lophs: the anterior and posterior lophs. The anterior loph consist of the anteroloph, the protocone and the paracone. The posterior loph consists of the hypocone, the metacone and the poster- oloph (Figure 4c). The posterior loph is very stable in all the species of Prosigmodon, and interestingly, the most basal Sigmodon, S. minor from early Blancan faunas has the same pattern as Prosigmodon (see fig. 4 in Peláez-Campomanes and Martin, 2005), this pattern is not observable in Sigmodon species from Rancholabrean-Recent. The recent Sigmodon species has a distinct M3, because the anterior loph is composed of the anteroloph and the protocone, and the posterior loph consist of the hypocone, the paracone, and the metacone.

Another important set of characters is related to the hypsodont grade of the tooth; these include the development of the central mure (arms connections between the principal cuspids in the molar center) and flexi (ids), the accessory cusp and lophs, and the straight flexi (ids) walls. For example, Prosigmodon species have mesodont teeth with accessory cusps, labial cingulum, and a tendency toward parallel alignment of flexi (ids) with the anteroposterior axis. These characters are more common on recent Democricetodontini and ancient Sigmodontini taxa (taken in part from Lindsay, 2008). Recent Sigmodon species have slightly more hypsodont teeth, but with simpler cusp morphology, lacking accessory cusp (ids) or cingulum, with narrow and oblique flexi (ids) and straight walls, heterogeneous enamel generally lacking on anterior walls of principal cusp (ids), and a tendency to develop lophodoncy.

\section{RESULTS OF THE PHYLOGENETIC ANALYSIS}

The result of the implicit enumeration is one most parsimonious tree of 77.183 steps, a CI of 0.693 and RI of 0.876 (Figure 6). The genus Prosigmodon appears in our analysis as a monophyletic group that excludes Prosigmodon chihuahuensis and includes Sigmodon minor. This group is supported only by one synapomorphy: character 4 , the

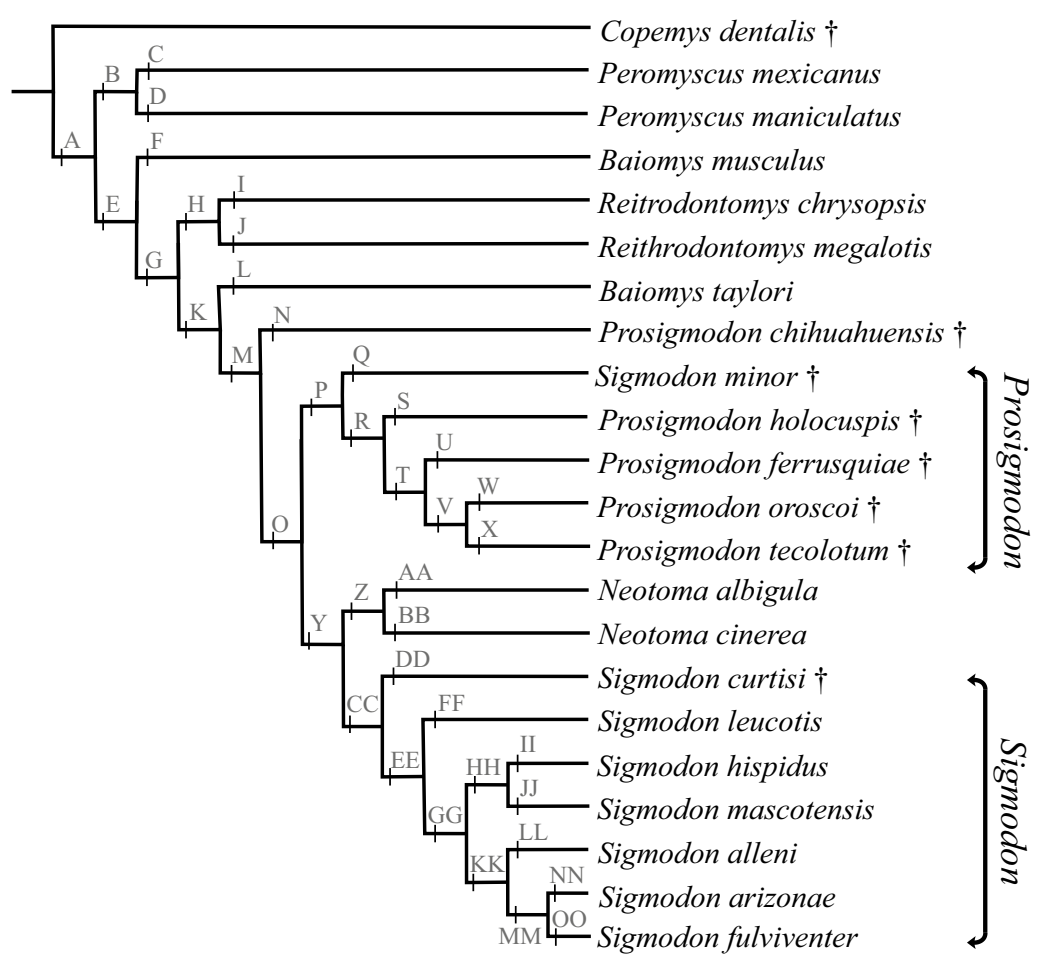

Figure 6. Most parsimonious phylogenetic tree (77.183 steps, $\mathrm{CI}=0.693$ and $\mathrm{RI}=0.876$ ) of Prosigmodon, Sigmodon and Neotomini species included in this work. Letters and nodes are synapomorphies or autapomorphies. The descriptions of the nodes are in Supplementary Table A4. $(\dagger)=$ Extinct taxon. 
ratio of the length of diastema and the $\mathrm{m} 1$ anteroposterior length is $1.582-1.634 \rightarrow 1.299$ (the ancestral character state is indicated before an arrow and then the apomorphic character) (node P in Figure 6; see description of all nodes in Supplementary Table A4). The Mexican species $P$. ferrusquiae, $P$. oroscoi and $P$. tecolotum are in a single group supported by one synapomorphy (node T in Figure 6 and Table A4): character one, the ratio of the anteroposterior length of M1 and the width of anterocone is $1.988 \rightarrow 2.157-2.186$. These species are in a clade with $P$. holocuspis (character 28, the anteroconid is connected to the protoconid). The species Prosigmodon tecolotum and P. oroscoi share one synapomorphy: character $11(0)$, the M1 anterocone is slightly bilobed in young specimens divided by a weakly anteromedian flexus, and the anterocone is expanded at the anterior base. The new species Prosigmodon tecolotum has three autapomorphies: character one, 2.157$2.186 \rightarrow 2.351$; character 17(1), a small but well distinguished mesoloph in M1 and M2; character 36 (1), m1 metaconid is isolated in young specimens (node X in Figure 6 and Table A4).

In our model Prosigmodon, Neotoma and Sigmodon are in a single group with two synapomorphies: character $1,2.003 \rightarrow 1.909-1.988$; character 40 , the anterolingual cingulum is not formed and the mesoflexid is open. The species of Neotoma and Sigmodon are in a clade strongly supported by 13 synapomorphies (node Y in Figure 6 and Table A4). The two species of Neotoma formed a group supported by ten synapomorphies (node Z in Figure 6 and Table A4). The Sigmodon species (except for $S$. minor) are grouped by three synapomorphies: character 15 (1), the anterior wall of anterocone is straight, without cingulum; character 22 (1), enamel poorly developed or absent in the posterior arms of the protocone and paracone of M1-M2; character $26(0)$, the anteroconid is not bilobed.

All the genera of Neotominae used in this analysis were well identified by synapomorphies, except Baiomys. The genus Peromyscus has two synapomorphies (character 12 (1), anteroloph of M1 is present; character 25 (1), in M3 the metacone is reduced or is not identifiable, the m3 seems to be composed of three cusps). The genus Reithrodontomys is supported by three synapomorphies (character 3, 1.879-2.248 $\rightarrow 2.280$; character 9 (1), upper incisors bifurcated; character 12 (1), anteroloph of $\mathrm{M} 1$ is present).

\section{DISCUSSION}

\section{The Prosigmodon clade and the first radiation of Sigmodontinae and Neotominae in Mexico}

Based on our phylogenetic analysis, Prosigmodon is a paraphyletic group as proposed by Rincón et al. (2016), however, our phylogenetic proposal differs in most of the branches from that proposed by these authors in their cladogram. To be monophyletic, the genus Prosigmodon should include $S$. minor and exclude $P$. chihuahuensis (Node P, Figure 6 and Table A4) if these species are correctly allocated to genera. The taxonomical similarity between S. minor and the Prosigmodon species was described by Peláez-Campomanes and Martin (2005) and was used to synonymize Prosigmodon and Sigmodon; they used an ample database of isolated teeth of Sigmodon minor and other indeterminate early Blancan species of Kansas for their evolutionary interpretations.

In our hypothesis, $S$. minor is the most basal species within Prosigmodon, followed by $P$. holocuspis, and the most apomorphic species are the Mexican Prosigmodon species based only in one synapomorphy: ratio of the anteroposterior length of $\mathrm{M} 1$ and the width of anterocone is $1.988 \rightarrow 2.157-2.186$. It is important to note that the morphological characters that Peláez-Campomanes and Martin (2005) proposed to establish plesiomorphic or apomorphic conditions in Prosigmodon species are not so important to define the relationship of the genus in our model: the hypsodonty (character 10), the shape of the anterocone and the anteroconid (characters 11 and 26) and the number of roots on $\mathrm{m} 1$ (character 33).

In our model, the genus Prosigmodon is not closely related to the modern Sigmodon species, unlike the phylogenetic hypothesis of Rincón et al. (2016) that proposed as single group S. minor and $S$. alstoni related to $P$. holocuspis supported by two synapomorphies: a reduced paraflexus and weakly hypsodont molars. It is important to note that $S$. minor and $S$. medius are varieties of the same species (Peláez-Campomanes and Martin, 2005), and Sigmodon alstoni is a South American taxon without a clear relationship with Prosigmodon, because some authors suggest that it is the most basal member of the Sigmodon genus (Peppers et al., 2002). Other authors think that is a monotypic clade of the same genus (Henson and Bradley, 2009). For these reasons, we only included common North American species in our phylogenetic analysis.

Our results suggests that Neotoma and Sigmodon are sister taxa, supported by 13 synapomorphies that include four metric indexes and nine discrete characters. The Neotoma clade is supported by ten synapomorphies and only one is a metric index. Some of the most important characters to distinguish Neotoma are: hypsodont molars, in the M1 and M2 the cusps are fused forming lophs (which also occurs in Sigmodon molars), the molars have three lophs, one anterior, one medial and one posterior; in $\mathrm{m} 1$ the connection between the anteroconid and the metaconid is complete, both cuspids form a single anterior lophid; the metaflexid and the hypoflexid in $\mathrm{m} 3$ are aligned in two symmetrical cuspids (Node Z in Figure 6 and Table A4).

The genus Sigmodon is subdivided into four species groups: I) Sigmodon curtisi; II) S. leucotis; III) S. hispidus and S. mascotensis; IV) Sigmodon alleni, S. arizonae and S. fulviventer. This arragement is partially similar to that of Martin (1979) who separated the genus into two groups by dental characteristics: an S. hispidus group (S. alleni, S. arizonae, S. fulviventer, S. hispidus, S. mascotensis, and S. ochragnathus), and S. leucotis group (S. alstoni, S. leucotis and S. peruanus). As can be seen, the groups III and IV correspond to most modern Sigmodon species (the group S. hispidus of Martin [1979]), and the basal lineages are $S$. curtisi (our group I) and S. leucotis (our group II similar to the group S. leucotis of Martin [1979] without S. alstoni).

The topology of the Sigmodon branch is very different from the systematic models based on nuclear sequences of Peppers et al. (2002) that include three species groups in Sigmodon: 1) hispidus (S. alleni, S. arizonae, S. hispidus, and S. mascotensis); 2) fulviventer (S. leucotis and S. fulviventer) and 3) alstoni (S. alstoni). Our Sigmodon branch also differs from the most recent phylogenetic hypothesis by Henson and Bradley (2009): group I (S. alleni, S. arizonae, S. hispidus, and S. mascotensis); group II (S. fulviventer and S. leucotis); group IV (S. alstoni). At present there is no phylogenetic study that includes dental morphological characters and DNA in Sigmodon or in other related groups. Certainly, there is no consensus in the Cricetidae infra-family groups between paleontologists and neontologists; many subfamilies and tribes do not have taxonomic compatibility amongst groups of fossil rodents with their current representatives (compare the phylogenetical hypotheses of Korth, 1994; Lindsay, 2008; Parada et al., 2013; Burgin et al., 2018). A detailed review of morphological and molecular data for Sigmodontinae and Neotominae is necessary to clarify this taxonomic discussion, but it is outside the objectives of the present paper.

The discrepancies are probably due to the phenotypic plasticity present in the group. Also, to the potential coevolution of the species of different genus in similar environments, which may affect our analysis based on dental morphological characters, even with the high values of consistency (CI of 0.693 ) and retention (RI of 0.876) that show few homoplasy. 


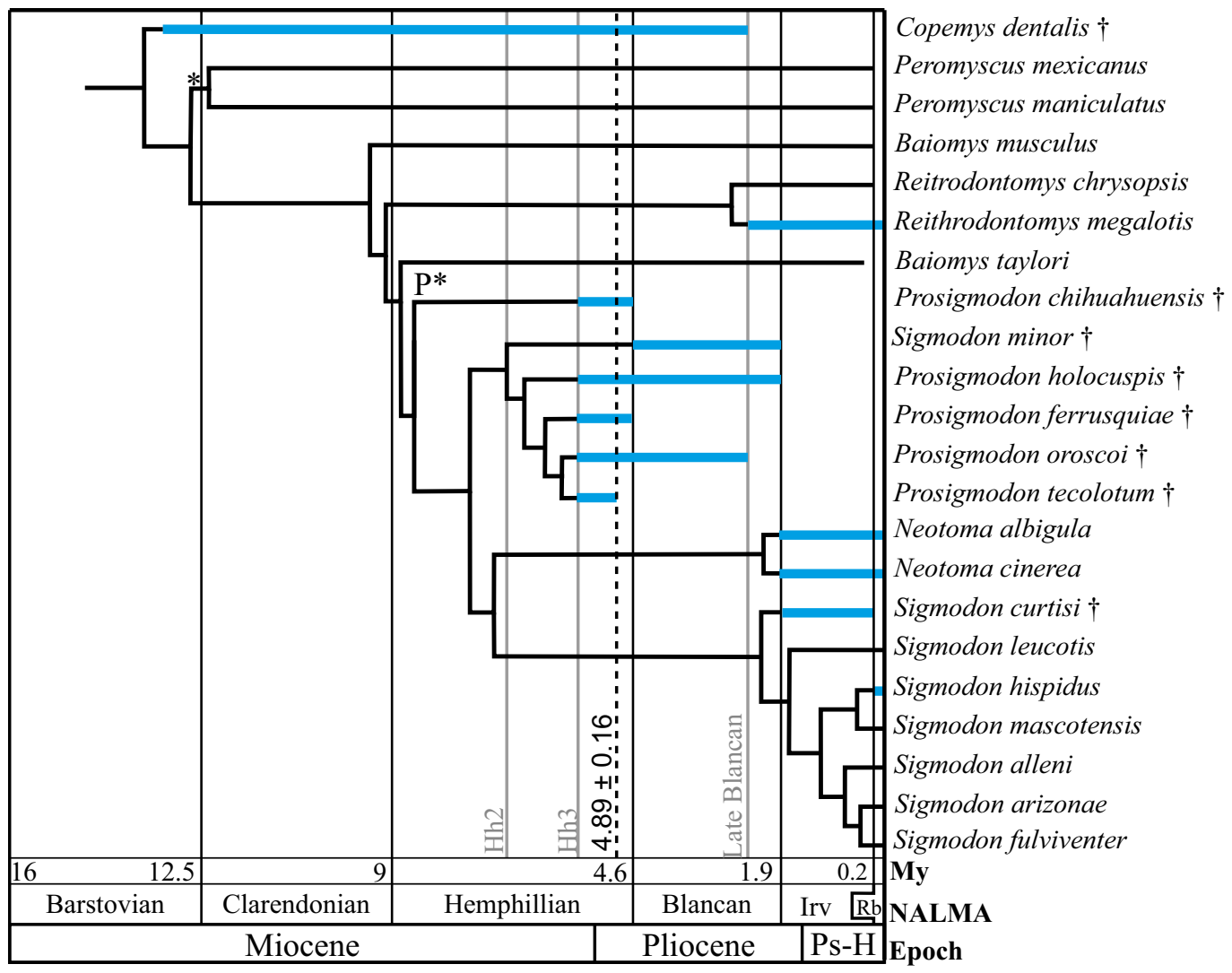

Figure 7. Chronogram of Sigmodontini species included in this work and its stratigraphic range. Thick blue lines indicate the stratigraphic range of species and simple black lines shows the phylogenetic model. The age of 4.89 Ma is of Kowallis et al. (1998). $\left(\mathrm{P}^{\star}\right)=$ First record of Prosigmodon sp. in the fauna of Dove Spring Formation, California (Whistler et al., 2009). $\left(^{*}\right)=$ First record of Peromyscus in Lindsay (2008), (†)=Extinct taxon. Abbreviations: Hh2, early late Hemphillian; Hh3, late Hemphillian; Irv, Irvingtonian; Rb, Rancholabrean; Ps-H, Pleistocene-Holocene.

The basal slip of Neotoma and Sigmodon clade started in the Hemphillian, but the record of the modern Sigmodon and Neotoma species occur during the Blancan (Figure 7). This geological time is interesting because important processes were interacting at the same time in central Mexico, the activity of the Trans-Mexican Volcanic Belt (Ferrari et al., 2012), the closure of the Isthmus of Panama, and the Great American Biotic Interchange (Woodburne, 2010). Probably these ecological dynamics shaped the current faunas of rodents.

Many species of herbivores evolved an adaptation to open landscapes dominated by grasses (Janis et al., 2002; Eronen et al., 2012). We observe a trend in the evolution of the Neotoma and Sigmodon species: both have an increase in diastemal length, greater hypsodonty with loss of accessory cusps and cingula, cusps tending to merge and simplify into lophs, in addition to narrower and oblique flexus (Figure 6 and Supplementary Table A4, node Y). All these characters have been reported in different groups of herbivorous mammals (e.g., Perissodactyla, Artiodactyla, Proboscidea) and correspond to adaptations driven by selection pressures involving the intake of grasses (Janis, 2002; Koenigswald et al., 2011; Tapaltsyan et al., 2016).

\section{Origin of Prosigmodon, and rodent faunal interchange between Mexico and USA}

The species of Prosigmodon attained their major diversity in the late Hemphillian of Mexico and southern North America; at least four of the five species of the genus occur in the principal stratigraphic sequences. But this genus probably evolved for the first time in California, in the early Hemphillian faunas from the Dove Spring Formation, where the first occurrence of Prosigmodon sp. was reported in concordance with other taxa that possibly are related with this group: Antecalomys, Copemys and Lindsaymys (Whistler et al., 2009; Kelly and Whistler, 2014). These records have not been described in detail, and a revision of the material of Prosigmodon and Copemys of Dove Spring Formation is necessary.

Our phylogenetic model suggests that Prosigmodon species of NA have more plesiomorphic charaters with respect to Sigmodon, and probably they started to range into boreal latitudes before colonizing central Mexico in the late Hemphillian. This interchange of rodents between NA and central Mexico probably was a common phenomenon. Later, the Mexican species started to be very diverse and abundant until the Hemphillian-Blancan boundary, all of them in the natural sister group to $P$. holocuspis. Different authors have proposed that the Mexican Prosigmodon species have more plesiomorphic characters than USA Prosigmodon species, like anterocone (id) shape, cusps (ids) connections, number of roots, among others (Jacobs and Lindsay, 1981; Lindsay and Jacobs, 1985; Carranza-Castañeda and Walton, 1992; Peláez-Campomanes and Martin, 2005). All of these characters were included in our analysis and were important to define the topology of our tree, but in our interpretation the Mexican species are more apomorphic when compared to $P$. holocuspis and $S$. minor.

The new record of $P$. tecolotum from Jalisco increased the Cricetidae diversity in central Mexico, a region that was very dynamic in geological and ecological processes during the Miocene-Pliocene (Woodburne, 2010; Ferrari et al., 2012). This is interesting because other Nearctic and Neotropical mammal groups have their center of diversification in the 
Trans-Mexican Volcanic Belt (Carranza-Castañeda, 2006; Wang and Carranza-Castañeda, 2008; Jiménez-Hidalgo and Carranza-Castañeda, 2010; Jiménez-Hidalgo and Carranza-Castañeda, 2011; CarranzaCastañeda et al., 2013; McDonald and Carranza-Castañeda, 2017). According to those previous studies, the central region of Mexico served as a center of diversification, refuge and corridor for faunas between North and South America during the GABI.

Our phylogenetic hypothesis is concordant with the major ecological and geological processes that possibly potentiated the evolution and interchange between faunas in North America during the MioceneRecent (Figure 7). This is because the tribe Sigmodontini had two pulses of radiation at that time. The first one was the evolution of the Prosigmodon lineage in the Clarendonian-Hemphillian of southern North America. This pulse was diachronic to the opening of the Gulf of California and the development of Basin and Range province (Henry and Aranda-Gomez, 2000; Dickinson, 2015), to the climate change in NA caused by alterations in oceanic currents (Eronen et al., 2012), and to the evolution of the drainage system in southwestern United States and northwestern Mexico (Aranda-Gómez et al., 2018). It should be noted that these data are consistent with the proposal of Vilela et al. (2013) that the initiation of Sigmodontini radiation occurred in the middle Miocene, previously to the GABI. The second radiation of Sigmodontini was the evolution of Sigmodon in the early Blancan, during the GABI, the end of the third episode of silicic volcanism in the formation of TMVB (Ferrari et al., 2012), and the aridification of NA (Eronen et al., 2012).

\section{CONCLUSIONS}

The new Prosigmodon tecolotum species from Tecolotlán, Jalisco is a new taxon of the Mexican Prosigmodon clade and is supported by three autapomorphies, two discrete characters and one continuous. Based on our phylogenetic hypothesis we propose that Prosigmodon is a paraphyletic group, not closely related with Sigmodon. However, Prosigmodon would be monophyletic if we include Sigmodon minor and exclude Prosigmodon chihuahuensis, but a more specific revision of $S$. minor/minor and S. minor/medius is necessary to support this hypothesis. Based on our phylogenetic model and morphological comparisons, we affirm that Prosigmodon is not a synonym of Sigmodon.

The record of Prosigmodon tecolotum increases the diversity of Prosigmodon species in central Mexico, and this finding supports the idea that central Mexico was a very important region for the evolution of small mammals, because the landscape was influenced by tectonic processes and the ecosystems evolved as a corridor area for faunas between North and South America during and after the GABI. It is possible that the Prosigmodon lineage diversified in NA during the Clarendonian-Hemphillian, prior to the diversification of the genera Sigmodon, and Neotoma in the Blancan.

The genera Sigmodon and Neotoma are recovered as sister taxa in a robust clade supported by 13 synapomorphies, and based on their apomorphic characters and their stratigraphic range we consider that these taxa are part of the last Sigmodontini and Neotomini radiation in North America, which maybe took place during the late Hemphillianearly Blancan boundary, in the early stages of GABI.

\section{ACKNOWLEDGEMENTS}

Our thanks to the Centro de Geociencias and Instituto de Geología, Universidad Nacional Autónoma de México (UNAM) for the institutional and financial support. This research was funded by project
PAPPIT 102817 and the NHM Student Collections Study Award (October 2018). We appreciate the help of Ilda Troncoso in the specimens collecting and preparation. We thank Jesús Alvarado, María del Carmen Perrillat and Violeta Romero for granting access to study the rodent material of the Colección Nacional de Paleontología, Instituto de Geología, UNAM. We thank Fernando Cervantes and Yolanda Hortelano for granting access to study the rodent material of the Colección Nacional de Mastozoología, Instituto de Biología, UNAM. Thanks to Xiaoming Wang, Samuel McLeod and Vanessa Rhue for the assistance in the study of material in the Vertebrate Palaeontology Collection, Natural History Museum of Los Angeles County (NHM); thanks to Jim Dinnes for his help in the study of rodent material in the Mammalogy Collection of NHM, and thanks to Giar Ann for helping in taking the photos at the Entomology department of NHM. Thanks to several field participants that collected the fossils, especially Earth Watch participants and students of Universidad Autónoma de Querétaro. Thanks to Isabel Sánchez for the help with English grammar. We acknowledge to Gabriela Contreras for the help in the field and figure edition. Thanks to Lucia Tovar for taking the SEM images in LANIVEG. We thank two anonymous reviewers, whose comments and suggestions have improved the clarity of the paper.

\section{SUPPLEMENTARY MATERIAL}

Supporting supplementary material can be found at the journal web site $<$ http://rmcg.unam.mx/>. This includes the tables of the revised taxa and their characters. In addition, the matrix in TNT format for the phylogenetic analysis.

\section{REFERENCES}

Aranda-Gómez, J.J., Carranza-Castañeda, O., Wang, X., Tseng, Z. J., Pacheco-Castro, A., 2018, Notes on the origin of extensive endorheic regions in central and northern Mexico, and some implications for paleozoogeography: Journal of South American Earth Sciences, 83, 55-67.

Baskin, J.A., 1978, Bensonomys, Calomys, and the origin of the Phyllotine group of neotropical Cricetines (Rodentia: Cricetidae): Journal of Mammalogy, 59(1), 125-135.

Bowdich, T.E, 1821, An analysis of the natural classifications of Mammalia for the use of students and travelers: J. Smith, Paris, France.

Burgin, C.J., Colella, J.P., Kahn, P.L., Upham N.S., 2018, How many species of mammals are there?: Journal of Mammalogy, 99(1), 1-14.

Carranza-Castañeda, O., 2006, Late Tertiary fossil localities in central Mexico, between $19^{\circ}-23^{\circ} \mathrm{N}, \mathrm{Pp}$ 45-60 in Carranza-Castañeda, O., Lindsay, E.H. (eds) Advances in late Tertiary vertebrate paleontology in Mexico and the Great American Biotic Interchange: Universidad Nacional Autónoma de México: Instituto de Geología and Centro de Geociencias, Publicación Especial, 4, 45-60.

Carranza-Castañeda, O., Walton, A., 1992, Cricetid rodents from the Rancho El Ocote Fauna, late Hemphillian (Pliocene), state of Guanajuato: Universidad Nacional Autónoma de México, Instituto de Geología, Revista, 10(1),71-93.

Carranza-Castañeda, O., Aranda-Gómez, J., Wang, X., Iriondo, A., 2013, The early late Hemphillian (Hh2) faunal assemblage from Juchipila Basin, State of Zacatecas, México and its biochronologic correlation with other Hemphillian faunas in central México: Contributions in Science, 521, 13-49.

Czaplewski, N.J., 1987, Sigmodont rodents (Mammalia; Muroidea: Sigmodontinae) from the Pliocene (early Blancan) Verde Formation, Arizona: Journal of Vertebrate Paleontology, 7, 183-199.

Dickinson, W.R., 2015, Integration of the Gila River drainage system through the Basin and Range province of southern Arizona and southwestern New Mexico (USA): Geomorphology, 236, 1-24. 
Eronen, J.T., Fortelius, M., Micheels, A., Portmann, F.T., Puolamäki, K., Janis, C., 2012, Neogene aridification of the Northern Hemisphere: Geology, 40(9), 823-826.

Farris, J., 1989, The retention index and the rescaled consistency index: Cladistics, 5, 417-419.

Ferrari, L., Orozco-Esquivel, T., Manea, V., Manea, M., 2012, The dynamic history of the Trans-Mexican Volcanic Belt and the Mexico subduction zone: Tectonophysics, 522-523, 122-149.

Gidley, J.W., Preliminary report on fossil vertebrates of the San Pedro Valley, Arizona, with descriptions of new species of Rodentia and Lagomorpha: United States Professional Paper 131-E, 119-131.

Goloboff, P.A., Farris, J.S., Nixon, K., 2008, TNT, a free program for phylogenetic analysis: Cladistics, 24, 774-786. doi:10.1111/j.1096-0031.2008.00217.x

Harris, A.H., 1984, Neotoma in the late Pleistocene of New Mexico and Chihuahua: Special Publication Carnegie Museum of Natural History, 8, 164-178.

Henson, D.D., Bradley, R. D., 2009, Molecular systematics of the genus Sigmodon: resuts from mitochondrial and nuclear gene sequences: Canadian Journal of Zoology, 87, 211-220, DOI:10.1139/Z09-005.

Henry, C.D., Aranda-Gomez, J.J., 2000, Plate interactions control middle-late Miocene, proto-Gulf and Basin and Range extension in the southern Basin and Range: Tectonophysics, 318, 1-26.

Janis, C.M., Damuth, J., Theodor, J.M., 2002, The origins and evolution of the North American grassland biome: the story from the hoofed mammals: Palaogeography, Palaeoclimatology, Palaeoecology, 177,183-198.

Jacobs, L.L., Lindsay, E.H., 1981, Prosigmodon oroscoi, a new Sigmodon rodent for the late Tertiary of Mexico: Journal of Paleontology, 5(2), 425-430.

Jacobs, L.L., Lindsay, E.H., 1984, Holarctic radiation of Neogene muroid rodents and the origin of South American cricetids: Journal of Vertebrate Paleontology, 4(2), 265-272.

Jiménez-Hidalgo, E., Carranza-Castañeda, O., 2010, Blancan camelids from San Miguel de Allende, Guanajuato, central Mexico: Journal of Paleontology, 81(1),51-65

Jiménez-Hidalgo, E., Carranza-Castañeda, O., 2011, The Pliocene pronghorn Hexobelomeryx fricki (mammalia: artiodactyla) from San Miguel de Allende, Guanajuato, central México: Revista Mexicana de Ciencias Geológicas, 28(3), 533-543.

Kelly, T.S., Whistler, D.P., 2014, New late Miocene (Latest Clarendonian to early Hemphillian) cricetid rodents from the upper part of the Dove Spring Formation, Mojave Desert, California: Paludicola, 10(1), 1-48.

Koenigswald, W.V., Holbrook, L.T., Kenneth, D.R., 2011, Diversity and evolution of Hunter-Schreger Band configuration in tooth enamel of perissodactyl mammals: Acta Paleontologica Polonica, 56(1), 11-32.

Korth, W.W., 1994, The Tertiary record of Rodents in North America, Topics in Geobiology: New York, Plenum Press, 319 pp.

Kowallis, B.J., Swisher, C.C., Carranza-Castañeda, O., Miller, W.E., Tingey, D.G., 1998, Preliminary radiometric dates in selected late tertiary vertebrate faunas from Mexico: Avances en Investigación, Paleontología de Vertebrados, Universidad Autónoma del Estado de Hidalgo, Publicación Especial, 1, 103-108.

Kowallis, B.J., Carranza-Castañeda, O., Miller, W.E., Christiansen, E. H., 2010, The Age and Geology of the Tecolotlán Graben, Jalisco, Mexico: Brigham Young University, Geology Studies, 48, 37-52.

Kowallis, B.J., Christiansen, E.H., Carranza-Castañeda, O., Miller, W.E., Ross, K.T., Tingey, D.G., 2017, The geology of the Tecolotlán Graben, Jalisco, Mexico: Geological Society of America Digital Map and Chart 22, 37 pp. doi:10.1130/2017.DMCH022.TXT

Lindsay, E.H. 2008. Cricetidae. in Janis, C.M., Gunnell G.F., Uhen, M. (eds), Evolution of Tertiary Mammals of North America. Volume 2: Small Mammals, Edentates, and Marine Mammals: Cambridge University Press, Cambridge, 456-479.

Lindsay, E.H., Jacobs, L., 1985, Pliocene small mammals fossils from Chihuahua, México: Universidad Nacional Autónoma de México, Instituto de Geología, Paleontología Mexicana, 51-53.

Martin, R.A., 1979, Fossil history of the genus Sigmodon: Evolutionary Monographs, 2, 1-36.

Martin, R.A., Hurt, R.T., Honey, J.G., Peláez-Campomanes, P., 2003, Late Pliocene and early Pleistocene rodents from the Northern Borchers Badlands (Meade County, Kansas), with comments on the Blancan-
Irvingtonian boundary in the Meade Basin: Journal of Paleontology, 77(5), 985-1001.

McDonald, H.G., Carranza-Castañeda, O., 2017, Increased xenarthran diversity of the Great American Biotic Interchange: a new genus and species of ground sloth (Mammalia, Xenarthra, Megalonychidae) from the Hemphillian (late Miocene) of Jalisco, Mexico: Journal of Paleontology, 91(5), 1069-1082. DOI: 10.1017/jpa.2017.45.

Parada, A., Pardiñas, U. F. J., Salazar-Bravo, J., D'Elía, G., Palma, E., 2013, Dating an impressive Neotropical radiation: molecular time estimates for the Sigmodontinae (Rodentia) provide insights into its historical biogeography: Molecular Phylogenetics and Evolution, 66, 960-968, DOI: http://dx.doi.org/10.1016/j.ympev.2012.12.001

Pardiñas, U.F., Lessa, G., Teta, P., Salazar-Bravo, J., Camara, E., 2014, A new genus of sigmodontine rodent from eastern Brazil and the origin of the tribe Phyllotini: Journal of Mammalogy, 95(2), 201-215.

Peláez-Campomanes, P., Martin, R., 2005, The Pliocene and Pleistocene history of cotton rats in the Meade Basin of Southwestern Kansas: Journal of Mammalogy, 86(3), 475-494.

Peppers, L.L., Carroll, D.S., Bradley, R.D., 2002, Molecular systematics of the genus Sigmodon (Rodentia: Muridae): evidence from the mitochondrial cytochrome-b gene: Journal of Mammalogy, 83(2), 396-407.

Reig, O.A., 1977, A proposed unified nomenclature for the enameled components of the molar teeth of the Cricetidae (Rodentia): Journal of Zoology of London, 181, 227-241.

Rincón, A.D., Czaplewski, N.J., Montellano-Ballesteros, M., Benammi, M., 2016, New species of Postcopemys (Cricetidae: Rodentia) from the early Pliocene of Lago de Chapala, Jalisco, Mexico: The Southwestern Naturalist, 61(2), 108-118, DOI: http://dx.doi.org/10.1894/15-00082R2.1

Rochebrune, A.T.D., 1883, Faune de la Sénégambie. Mammiferes: Actea Societe Linnéenne (Bordeaux), 37, 49-203.

Steppan, S.J., 1995, Revision of the tribe Phyllotini (Rodentia: Sigmodontinae), with a phylogenetic hypothesis for the Sigmodontinae: Fieldiana Zoology, New Series 80, 1-112.

Tapaltsyan, V., Charles, C., Hu, J., Mindell, D., Ahituv, N., Wilson, G.M., Black, B.L. Viriot, L., Ophir, K., 2016, Identification of novel Fgf enhancers and their role in dental evolution: Evolution \& development, 18(1), 31-40.

Tomida, Y., 1987, Small mammal fossils and correlation of continental deposits, Safford and Duncan basins, Arizona, USA: National. Science Museum, Tokyo. Science Museum Monographs, 3, 1-141.

Vilela, J.F., Mello, B., Voloch, C.M., Schrago C.G., 2013, Sigmodontine rodents diversified in South America prior to the complete rise of the Panamanian Isthmus: Journal of Zoological Systematics and Evolutionary Research, 52(3), 249-256

Wagner, J.A., 1843, Archiv für Naturgeselschaft, 9, 52.

Wang, X., Carranza-Castañeda, O., 2008, Earliest hog-nosed skunk, Conepatus (Mephitidae, Carnivora), from the early Pliocene of Guanajuato Mexico and origin of South American skunks: Zoological Journal of the Linnean Society, 154, 386-407.

Weksler, M., 2006, Phylogenetic relationships of oryzomine rodents (Muroidea: Sigmodontinae): separate and combined analyses of morphological and molecular data: Bulletin of the American Museum of Natural History, 296, 1-149.

Whistler, D.P., Tedford, R.H., Takeuchi, G.T., Wang, X., Tseng, Z.J., Perkins, M.E., 2009, Revised Miocene biostratigraphy and biochronology of the Dove Spring Formation, Mojave Desert, California: Museum of Northern Arizona Bulletin, Papers on Geology, Vertebrate Paleontology, and Biostratigraphy in Honor of Michael O. Woodburne, 65, 331-362.

Wood, A.E., Wilson, R.W., 1936, A suggested nomenclature for the cusp of the cheek teeth of rodents: Journal of Paleontology, 10(5), 388-391.

Woodburne, M.O., 2010, The Great American Biotic Interchange: Dispersals, Tectonics, Climate, Sea Level and Holding Pens: Journal of Mammal Evolution, 17, 245-264.

Manuscript received: january 16, 2019

Corrected manuscript received: may 8, 2019

Manuscript accepted: may 28, 2019 